\title{
Identification of novel single nucleotide polymorphisms in the DGAT1 gene of buffaloes by PCR-SSCP
}

Ashwin A. Raut ${ }^{1}$, Anil Kumar ${ }^{2}$, Sheo N. Kala ${ }^{3}$, Vinod Chhokar ${ }^{2}$, Neeraj Rana ${ }^{3}$, Vikas Beniwal ${ }^{4}$, Sundeep Jaglan ${ }^{5}$, Sachin K. Samuchiwal ${ }^{2}$, Jitender K. Singh ${ }^{3}$ and Anamika Mishra ${ }^{1}$

${ }^{1}$ High Security Animal Disease Laboratory, Bhopal, Madhya Pradesh, India.

${ }^{2}$ Department of Bio \& Nano Technology, Guru Jambheshwar University of Science \& Technology, Hisar, Haryana, India.

${ }^{3}$ Central Institute for Research on Buffalo, Hisar, Haryana, India.

${ }^{4}$ Department of Biotechnology, Maharishi Markandeshwar University, Mullana, Ambala, Haryana, India.

${ }^{5}$ Indian Institute of Integrative Medicine, Jammu, Jammu \& Kashmir, India.

\begin{abstract}
Diacylglycerol O-acyltransferase 1 (DGAT1) is a microsomal enzyme that catalyzes the final step of triglyceride synthesis. The DGAT1 gene is a strong functional candidate for determining milk fat content in cattle. In this work, we used PCR-SSCP (polymerase chain reaction-single-strand conformation polymorphism) and DNA sequencing to examine polymorphism in the region spanning exon 7 to exon 9 of the DGAT1 gene in Murrah and Pandharpuri buffaloes. Three alleles (A, B and $C$ ) and four novel single-nucleotide polymorphisms were identified in the buffalo DGAT1 gene. The frequencies of the alleles differed between the two buffalo breeds, with allele $C$ being present in Murrah but not in Pandharpuri buffalo. The allele variation detected in this work may influence DGAT1 expression and function. The results described here could be useful in examining the association between the DGAT1 gene and milk traits in buffalo.
\end{abstract}

Key words: buffalo, DGAT1, PCR-SSCP, polymorphism, SNP.

Received: July 28, 2011; Accepted: April 27, 2012.

Diacylglycerol O-acyltransferase 1 (DGAT1) is one of the key enzymes in controlling the rate of triglyceride synthesis in adipocytes. Since the DGAT1 gene maps to the quantitative trait loci (QTL) for milk fat percentage in the centromeric region of chromosome 14 (BTA14), this gene has been studied as a candidate for association with the milk fat content in cattle. Mutation analysis in cattle has revealed 19 polymorphic sites within the DGAT1 gene (Winter et al., 2002). Among these polymorphisms the GC/AA exchange at positions 10433/10434 (GenBank accession no. AJ318490) in exon 8 that results in a $K 232 A$ amino acid exchange was found to affect the milk fat content (Spelman et al., 2002; Boichard et al., 2003) and has been extensively studied in several cattle populations (Lacorte et al., 2006). The influence of DGAT1 K232A on milk fat content differs among populations (Spelman et al., 2002; Thaller et al., 2003), suggesting that further variations in the genomic region of DGAT1 may be involved. In this context, polymorphism in the promoter region has been reported to have

Send correspondence to Ashwin A Raut. High Security Animal Disease Laboratory, IVRI, Kokta Road, Anand Nagar, 46212 Bhopal, MP, India. E-mail: ashwin.hsadl@gmail.com. functional relevance for DGAT1 transcription (Kühn et al., 2004).

Buffaloes are the major milk-producing domestic animals in India, with a milk fat content ranging from $7 \%$ to $11 \%$ among different breeds. DGAT1 $K$ is reported to be fixed in five Indian breeds of buffalo (Tantia et al., 2006). Since the regulation of DGAT1 expression in adipocytes occurs largely at the transcriptional and post-transcriptional levels (Yu et al., 2002) it is possible that mutations in the introns and untranslated regions may also influence DGAT1 expression and, consequently, the milk fat content. The aim of this study was to examine the polymorphism in introns 7 and 8 of the DGAT1 gene in Murrah and Pandharpuri buffaloes using polymerase chain reaction-singlestrand conformation polymorphism (PCR-SSCP), a rapid, precise technique that allows the identification of singlenucleotide polymorphisms (SNPs).

Forty-four buffaloes (22 Murrah and 22 Pandharpuri) reared in different agroclimatic areas were used in this study. Murrah is the major buffalo breed on northern India whereas Pandharpuri is from western India. High milk yields and breed-specific traits were the main selection cri- 
teria in both cases. Unrelated animals reared in the districts of Rohtak, Hisar, Jind and Bhiwani in the case of Murrah and in the districts of Solapur, Sangli and Kohlapur in the case of Padharpuri buffaloes were sampled and only healthy animals with the characteristic traits of each breed were studied.

Ten millilitres of venous blood was collected from each animal into tubes containing $500 \mu \mathrm{L}$ of $2.7 \%$ EDTA as anticoagulant. The samples were transported to the laboratory on ice and stored at $-20{ }^{\circ} \mathrm{C}$ until isolation of genomic DNA. Genomic DNA was isolated from $5 \mathrm{~mL}$ of blood by the phenol-chloroform extraction method (Sambrook and Russel, 2001). The quality and purity of the isolated DNA were determined by agarose gel electrophoresis and spectrophotometry, respectively. The DNA samples that showed a single band on agarose gel and had an $\mathrm{A}_{260 \mathrm{~nm}} / \mathrm{A}_{280 \mathrm{~nm}}$ ratio of $\sim 1.8$ were used for further analysis. DNA was quantified by comparison with lambda DNA of known concentration in $0.8 \%$ agarose gels.

A region of the buffalo DGAT1 gene spanning parts of exon 7 and exon 9 (including intron 7, exon 8 and intron 8 entirely) was amplified by PCR using forward (5'-GCACCATCCTCTTCCTCAAG-3') and reverse (5'-GGAAGCGCTTTCGGATG-3') primers (Winter et al., 2002). Although this region of the buffalo gene has already been amplified and sequenced by others (Tantia et al., 2006), in the present study we used PCR-SSCP to examine polymorphism in the exon 7 to exon 9 region of the gene. The PCR mixture (final volume: $25 \mu \mathrm{L}$ ) contained $10 \mathrm{pM}$ of each primer, $100 \mu \mathrm{M}$ of each dNTP, $1.5 \mathrm{mM}$ $\mathrm{MgCl}_{2}, 100 \mathrm{ng}$ of genomic DNA as template and $1 \mathrm{U}$ of Taq DNA polymerase (Fermentas) in PCR buffer. The samples were denatured at $94{ }^{\circ} \mathrm{C}$ for $5 \mathrm{~min}$ and then subjected to 35 cycles of $94^{\circ} \mathrm{C}$ for $30 \mathrm{~s}, 56^{\circ} \mathrm{C}$ for $30 \mathrm{~s}$ and $72^{\circ} \mathrm{C}$ for $30 \mathrm{~s}$, with a final extension at $72{ }^{\circ} \mathrm{C}$ for $5 \mathrm{~min}$. The length of the amplified fragment was $411 \mathrm{bp}$ in both breeds.

Four microliters of each PCR product was mixed with $14 \mu \mathrm{L}$ of formamide loading buffer $(0.05 \%$ xylene-cyanole, $0.05 \%$ bromophenol blue, $5.5 \mathrm{mM}$ EDTA, $\mathrm{pH} 8.0$, in formamide) and forward and reverse primer solution (final concentration: $150 \mathrm{nM}$ ), denatured at $95^{\circ} \mathrm{C}$ for $5 \mathrm{~min}$ and snap-chilled on ice for at least $10 \mathrm{~min}$. Samples were then loaded onto a non-denaturing $15 \%$ polyacrylamide gel (acrylamide:bis-acrylamide ratio of 49:1) and electrophoresis was done at $10{ }^{\circ} \mathrm{C}$ in $0.5 \mathrm{X}$ TBE buffer $(89 \mathrm{mM}$ Tris, $89 \mathrm{mM}$ boric acid, $2 \mathrm{mM}$ EDTA, $\mathrm{pH} 8.3$ ) for $20 \mathrm{~h}$ at $200 \mathrm{~V}$. The bands were silver stained (Bassam et al., 1991). Two PCR products corresponding to each of the different PCRSSCP alleles/patterns identified were purified using PCR product purification kits (Qiagen) and sequenced by an automated dye terminator cycle sequencing method in an $\mathrm{ABI}$ PRISM 377 DNA sequencer. The sequences were analyzed using DNASTAR Lasergene 7.0 sequence analysis software to identify SNPs in the different PCR-SSCP alleles.
SSCP detects single-base sequence changes by abnormal electrophoretic migration of one or both single strands in a non-denaturing polyacrylamide gel (Gruszczynska et al., 2005). Four PCR-SSCP patterns were observed in Murrah buffaloes while only two patterns were seen in Pandharpuri buffaloes (Figure 1). Since singlestranded DNA (ssDNA) usually yields two bands for homozygotes and four for heterozygotes the patterns were denominated as genotypes AA, AB, BB and AC in Murrah and as $\mathrm{AA}$ and $\mathrm{AB}$ in Pandharpuri. The lower band in the AC genotype sample could not be separated. Similar results have also been reported for a heterozygous genotype of the kappa-casein bovine gene for which only three PCR-SSCP bands were confidently identified (Barroso et al., 1998).

The addition of forward and reverse primers (final concentration of each primer: $150 \mathrm{nM}$ ) to the gel loading mixture greatly improved the resolution and reproducibility of the SSCP bands. This finding confirmed the idea that primer addition during SSCP analysis leads to hybridization of the primer with ssDNA, reduces DNA reannealing and affects the mobility and sensitivity of the SSCP bands (Zhu et al., 2006). However, despite this manoeuver, an additional band was observed in all of the samples with allele A, i.e., genotypes AA, AB and AC. Since this band was not seen in the BB genotype and since sequencing of the PCR products of the AA genotype revealed no discrepancy between the sequences of different samples or the forward and reverse sequences, we concluded that the additional band was an alternative form of the allele A DNA sequence. This conclusion agrees with the demonstration that strands with the same sequence may yield different stable confor-

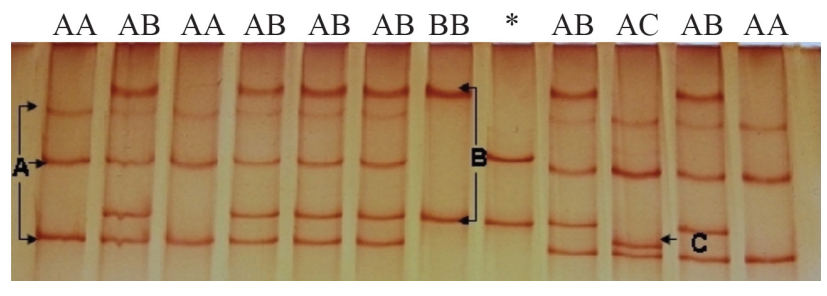

Figure 1 - Silver-stained polyacrylamide gel showing the PCR-SSCP patterns of alleles of the DGAT1 gene amplified from genomic DNA of Murrah and Pandharpuri buffalo. The SSCP-derived genotypes are indicated at the top of each lane. Bands A, B and C in lanes AA, BB and AC, respectively, indicate the alleles identified in this work. *PCR-SSCP pattern of the DGAT1 gene fragment amplified from sheep (control).

Table 1 - Nucleotide substitutions in the PCR-SSCP alleles of the buffalo DGAT1 gene.

\begin{tabular}{lcccc}
\hline Allele (Accession number) & \multicolumn{4}{c}{ Nucleotide positions* } \\
\cline { 2 - 5 } & 75 & 136 & 256 & 277 \\
\hline A (DQ886485) & C & C & C & G \\
B (FJ014704/FJ014706) & C & G & T & G \\
C (FJ014705) & A & C & C & T \\
\hline
\end{tabular}

*Based on the sequence in GenBank, accession number FJ014704. 
Table 2 - Genotype and allele frequencies based on PCR-SSCP analysis of the DGAT1 gene in Murrah and Pandharpuri buffaloes.

\begin{tabular}{|c|c|c|c|c|c|c|c|}
\hline \multirow[t]{2}{*}{ Breed } & \multicolumn{4}{|c|}{ Genotype frequency } & \multicolumn{3}{|c|}{ Allele frequency } \\
\hline & $\mathrm{AA}$ & $\mathrm{AB}$ & $\mathrm{BB}$ & $\mathrm{AC}$ & A & B & $\mathrm{C}$ \\
\hline Murrah $(n=22)$ & 0.27 & 0.55 & 0.09 & 0.09 & 0.59 & 0.36 & 0.05 \\
\hline Pandharpuri $(n=22)$ & 0.45 & 0.55 & - & - & 0.73 & 0.27 & - \\
\hline
\end{tabular}

mations known as isoconformers (Ripoli et al., 2006; Chessa et al., 2010).

Samples with different PCR-SSCP patterns were sequenced to identify the underlying SNP. The sequences have been deposited in GenBank under accession numbers FJ014704 (allele B in Murrah), FJ014705 (allele C in Murrah) and FJ014706 (allele B in Pandharpuri). Polymorphism was seen as a substitution at four positions (Table 1). Seven SNPs have been reported based on PCR-SSCP studies of the entire DGAT1 gene in Chinese buffalo (Yuan et al., 2007) and 19 SNPs (DQ886485) were reported based on sequencing studies in Indian buffalo (Mishra et al., 2007), but none have been reported for the region studied here. The sequence of allele A identified here was identical to that reported for the DGAT1 gene in Indian buffalo (DQ886485). Alleles B and C were novel and differed from allele $\mathrm{A}$ at two positions each, whereas allele $\mathrm{B}$ differed from $\mathrm{C}$ at four positions; the sequences of all three alleles differed from those of Chinese buffalo (AY999090). Three PCR-SSCP alleles have been reported in the DGAT1 gene fragment spanning the region studied here, with two of the alleles being different confirmations of the same sequence (Ripoli et al., 2006). In contrast, the sequences of the three alleles identified here differed from each other.

The GC/AA substitution in exon 8 of the DGAT1 gene in cattle has been associated with milk fat content (Winter et al., 2002; Weller et al., 2003; Grisart et al., 2004). Exon 8 however, was found to be conserved in the three PCR-SSCP alleles identified here. This finding agrees with reports that DGAT1 $K$, which is associated with a high milk fat content, is fixed in Indian cattle and buffalo breeds (Tantia et al., 2006). Table 2 shows that the allele and genotype frequencies varied between the two breeds studied here (Table 2). The presence of allele C only in heterozygous individuals and only in Murrah buffaloes indicated that this may be a mutation specific to the Murrah breed or a rare allele in Pandharpuri buffaloes (Falconer and Mackay, 1996).

The SNPs identified here occurred in introns 7 and 8 of the DGAT1 gene. Polymorphisms in introns affect the functionality of genes for enzymes such as endothelial nitric oxide synthase (Buraczynska et al., 2004) and the cytochrome P450 isoenzyme CYP1A2 (Sachse et al., 1999). Since the DGAT1 gene is also an enzyme gene, the SNPs identified here may influence the functionality of this gene, i.e., its effect on milk fat content, which varies markedly among Indian buffalo breeds. In this regard, a phylo- geographic study (Berrebi et al., 2005) of large populations of different buffalo breeds would be useful in determining the general distribution of the alleles identified in this study.

In conclusion, the buffalo DGAT1 gene shows considerable genetic variation and contains several novel SNPs. The variation in the distribution of several alleles between Pandharpuri and Murrah buffalo, which also differ markedly in their milk fat content, indicates a need for studies on the association between these SNPs and milk fat content. The findings described here should be useful in determining the role that DGAT1 plays in regulating milk fat synthesis and in improving the quality of buffalo milk.

\section{References}

Barroso A, Dunner S and Canon J (1998) Detection of bovine kappa-casein variants $\mathrm{A}, \mathrm{B}, \mathrm{C}$, and $\mathrm{E}$ by means of polymerase chain reaction-single strand conformation polymorphism (PCR-SSCP). J Anim Sci 76:1535-1538.

Bassam BJ, Caetano-Anolles G and Gresshoff PM (1991) Fast and sensitive silver staining of DNA in polyacrylamide gels. Anal Biochem 196:80-83.

Berrebi P, Boissin E, Fang F and Cattaneo-Berrebi G (2005) Intron polymorphism (EPIC-PCR) reveals phylogeographic structure of Zacco platypusin China: A possible target for aquaculture development. Heredity 94:589-598.

Boichard D, Grohs C, Bourgeois F, Cerqueira F, Faugeras R, Neau A, Rupp R, Amigues Y, Boscher MY and Levéziel H (2003) Detection of genes influencing economic traits in three French dairy cattle breeds. Genet Sel Evol 35:77-101.

Buraczynska M, Ksiazek P, Zaluska W, Nowicka T and Ksiazek A (2004) Endothelial nitric oxide synthase gene intron 4 polymorphism in patients with end-stage renal disease. Neph Dial Transp 19:2302-2306.

Chessa S, Rignanesec D, Berbennib M, Ceriotti G, Martinid M, Pagnaccob G and Carolic A (2010) New genetic polymorphisms within ovine $\beta$ - and $\alpha$ S2-caseins. Small Rumin Res 88:84-88.

Falconer DS and Mackay TFC (1996) Introduction to Quantitative Genetics. 4th edition. Longmans Green, Harlow, 43 pp.

Grisart B, Farnir F, Karim L, Cambisano N, Kim JJ, Kvasz A, Mni M, Simon P, Frère JM, Coppieters W, et al. (2004) Genetic and functional confirmation of the causality of the DGAT1 K232A quantitative trait nucleotide in affecting milk yield and composition. Proc Natl Acad Sci USA 101:2398-2403.

Gruszczynska J, Brokowska K, Charon KM and Swiderek WP (2005) Restriction fragment length polymorphism of exon 2 Ovar-DRB1 gene in Polish Heath Sheep and Polish Lowland Sheep. J Appl Genet 46:311-314. 
Kühn C, Thaller G, Winter A, Bininda-Emonds ORP, Kaupe B, Erhardt G, Bennewitz J, Schwerin M and Fries R (2004) Evidence for multiple alleles at the DGAT1 locus better explains a quantitative trait locus with major effect on milk fat content in cattle. Genetics 167:1873-1881.

Lacorte GA, Machado MA, Martinez ML, Campos AL, Maciel RP, Verneque RS, Teodoro RL, Peixoto MGCD, Carvalho MRS and Fonseca CG (2006) DGAT1 K232A polymorphism in Brazilian cattle breeds. Genet Mol Res 5:475-482.

Mishra B, Tantia MS, Kumar STB and Vijh RK (2007) Characterization of the DGATIgene in the Indian buffalo (Bubalus bubalis). Genet Mol Biol 30:1097-1100.

Ripoli MV, Corva P and Giovambattista G (2006) Analysis of a polymorphism in the DGAT1 gene in 14 cattle breeds through PCR-SSCP methods. Res Vet Sci 80:287-290.

Sachse C, Brockmöller J, Bauer S and Roots I (1999) Functional significance of a $\mathrm{C} \rightarrow \mathrm{A}$ polymorphism in intron 1 of the cytochrome P450 CYP1A2gene tested with caffeine. Br J Clin Pharmacol 47:445-449.

Sambrook J and Russel DW (2001) Molecular Cloning: A Laboratory Manual. 3rd edition. Cold Spring Harbor Laboratory Press, New York, 616 pp.

Spelman RJ, Ford CA, McElhinney P, Gregory GC and Snell RG (2002) Characterization of the DGAT1 gene in the New Zealand dairy population. J Dairy Sci 85:3514-3517.

Tantia MS, Vijh RK, Mishra BP, Mishra B, Kumar BST and Sodhi M (2006) DGAT1 and ABCG2 polymorphism in In- dian cattle (Bos indicus) and buffalo (Bubalus bubalis) breeds. BMC Vet Res 2:e32.

Thaller G, Krämer W, Winter A, Kaupe B, Erhardt G and Fries R (2003) Effects of DGAT1 variants on milk production traits in German cattle breeds. J Anim Sci 81:1911-1918.

Weller JI, Golik M, Seroussi E, Ezra E and Ron M (2003) Population-wide analysis of a QTL affecting milk-fat production in the Israeli Holstein population. J Dairy Sci 86:2219-2227.

Winter A, Kramer W, Werner FAO, Kollers S, Kata S, Durstewitz G, Buitkamp J, Womack JE, Thaller G and Fries R (2002) Association of a lysine-232/alanine polymorphism in a bovine gene encoding acyl-CoA: Diacylglycerol acyltransferase (DGAT1) with variation at a quantitative trait locus for milk fat content. Proc Natl Acad Sci USA 99:9300-9305.

Yu YH, Zhang Y, Oelkers P, Sturley SL, Rader DJ and Ginsberg HN (2002) Posttranscriptional control of the expression and function of diacylglycerol acyltransferase-1 in mouse adipocytes. J Biol Chem 277:50876-50884.

Yuan J, Zhou J, Deng X, Hu X and Li N (2007) Molecular cloning and single nucleotide polymorphism detection of buffalo DGAT1 gene. Biochem Genet 45:611-621.

Zhu X, Niu N, Liu Y, Du T, Chen D, Wang X, Gu HF and Liu Y (2006) Improvement of the sensitivity and resolution of PCR-SSCP analysis with optimized primer concentrations in PCR products. J Genet 85:233-235.

\section{Associate Editor: Alexandre Rodrigues Caetano}

License information: This is an open-access article distributed under the terms of the Creative Commons Attribution License, which permits unrestricted use, distribution, and reproduction in any medium, provided the original work is properly cited. 